\title{
The Camp and the Home
}

\section{Europe as Myth and Metaphor}

\author{
Joep Leerssen
}

\begin{abstract}
This contribution attempts to reduce the complexity of the manifold images of Europe's position in the world with the help of the imagological method. It outlines an evolving and progressively more entangled dialectics as a successively shrinking 'Europe' was opposed, either in negative or positive terms, to a growing lineage of Others. The process takes us from a large and open-bordered Europe in Classical Antiquity to a concentrated and more self-enclosed Northern-Eurozone Europe in its recent polarisation between postcolonial/post-totalitarian guilt and resurgent populist xenophobia. Throughout this long and complex history, the classical notion of the House (oikos, domus) has continued to inform European self-images. For better or worse, Europe sees itself in terms of its fundamental domesticity.
\end{abstract}

\section{Europe as Frame, Europe Framed}

How do we frame Europe? It is a key insight in imagology that the image of a given 'nation' is always conceived in a discourse of contrast, even if that contrast is elided or left implicit. To observe that the French are frivolous or that the English have a stiff upper lip, means, implicitly or explicitly, to observe how this attribute renders them different from the non-French or non-English. Nations are most characteristically themselves (so the assumption goes) in precisely those aspects in which they are most noticeably different from other nations. For imagologists, this means that our analysis of ethnotypes will always involve an unpacking of the implied contradistinctions, and to establish what Others are used as a background against which the reputed 'character' or 'identity' of a nation is silhouetted. ${ }^{1}$

1 On the theory and method of imagology, generally: Beller, Leerssen (2007); Dyserinck (2015); Leerssen (2016a) and the website www.imagologica.eu.

(C) JOEP LEERSSEN, 2021 | DOI:10.1163/9789004436107_008

This is an open access chapter distributed under the terms of the CC BY-NC-ND 4.0 license. 
If, then, an imagologist were to approach the vexed question of what constitutes a European 'identity' (a topic which has attracted inordinate amounts of punditry: hundreds of books and essays which invariably begin with intense hand-wringing on the utter impossibility of defining Europe), his/her first reflex would be to unpack the implied contrast-frame: a 'European identity' as opposed to what, precisely? As opposed to America, or Asia, or Africa? The resulting European ethnotype would take on very different characteristics in each of these contrast-frames: Europe-as-opposed-to-America would be a continent of mixed feelings, ironies, 'negative capability' and a weary, disenchanted refinement as opposed to American vigour, brashness and energetic naiveté. (Examples: Major Calloway vs. Holly Martins in The Third Man; Humbert Humbert vs. Lolita in Nabokov's novel.) Europe as opposed to Asia evokes connotations of historical development and civil society vs. the unchanging presence of pre-civic traditionalism and a propensity towards 'Oriental despotism'. Europe vs. Africa evokes different stereotypical frames again: self-imposed social order vs. the brute force of nature. And so 'Europe' can be framed, from case to case, as the continent of mixed feelings, civil society and social order; of Rembrandt and Captain Cook, Auschwitz and Chartres; scientific achievement and enervated decline; Augustine, Erasmus, Torquemada, Tolstoy, Mussolini and Derrida.

It is for that reason that the Imagology handbook, edited by Manfred Beller and myself, ${ }^{2}$ abstained from carrying an entry on, of all places, Europe. Imagology offers profiles of ethnotypes from 'Albanian' to 'Turkish'; it contains articles surveying eurocentric attitudes towards global regions from Africa to Polynesia. There is even an entry on 'Ethnocentrism and eurocentrism'; but an article on 'Europe' as such is lacking. Europe is, as it were, the hole in that book's donut. The omission was a deliberate one: Europe was, if anything, the implied contrast-frame against which all exoticisms listed in the book were silhouetted, and as such proved too complex, too shape-shifting, to be covered within the book's scope.

I have attempted to remedy that hollow core at the centre of imagology in a subsequent book (in Dutch), which in free-floating essayistic form tried to come to terms with the shape-shifts in the European self-image. ${ }^{3}$ Following on from that attempt I will in the following pages try to systematize some imagological insights and use them to throw light on the recent crises in Europe's self-positioning in the world.

2 See Beller, Leerssen (2007).

3 Leerssen (2016b). 
The imagologist's first reflex is to situate a given ethnotype in its implied contrast-frame: to set off a purported Identity against its implied Other. There is a curious correlation between the number of potential Others a given identity has and its hegemonic position in our discourse. The very fact that 'Europe' can be silhouetted against so many others is a sign of its central position in our discursive configuration of ethnotypes about the world (this is what made Europe the gravitational Black Hole at the galactic centre of the Imagology handbook.) Subaltern nationalities tend to have their ethnotype dominated by one overriding binary opposition. In the racial view of humankind à la Blumenbach, Black is defined vis-à-vis White; so is Red, or Yellow. But White has all three as its reservoir of potential Others. The Irish ethnotype tends to be wholly dominated by its contrastive pairing with 'English'; but Englishness can also be set off against Scottish, German, French etcetera.

The multiplicity of Others for an image of Europe is, then, a given which needs to be addressed and analysed. And so the imagologist's first reflex calls forth the immediate necessity of applying the method's second reflex: that of historicising.

Imagology is not a method in the social sciences but in the humanities, and as such its awareness of historical change is of categorical importance. Ethnotypes are part of a historical development and behind their short-term fixity and apparent rigidity we need to capture their long-term variability and changeability. The character-traits attributed to nations are presented to us as immutable anthropological fixities: Russians 'just are' predisposed to patient resignation, Italians are naturally ebullient, Swedes cerebral and introspective. But in practise the documentary evidence shows that for every stiff-upper-lipped English Phileas Fogg there is a violent, brawling Vin Jones, for every earthy French Gérard Depardieu there is a rigid, cartesian Michel Barnier, for every dreamy Irish Enya there is a tough-as-nails Bernadette Devlin, all of whom are considered equally 'representative' of their alleged 'national character'. In historicising those contradictory variations - setting out their manifestations in the documentary record along a time-line - we notice that the ethnotype available nowadays is the cumulative end result of a centuries-long historical dialectics, in which earlier ethnotypes, dominant in one period, had called forth their own contrary opposites. Much of the imagologist's work consists in analysing the superimposed strata of this ethnotypical sedimentation into the successive periods of its historical development.

I should point out in this context that the cultural history of ideas, unlike the social history of events, is cumulative rather than successive; it works by 
accretion rather than replacement. Later ideas do not replace or oust older ideas, but are superadded on top of them. The old remains available underneath the new. The Beatles do not abolish Bach, nor does the recent 'sociopathic murderer' ethnotype of 'nordic noir' crime thrillers abolish the earlier Scandinavian ethnotypes of serene reasonableness (I KEA, Astrid Lindgren) or anguished moralism (Ingmar Bergman).

And so the question becomes: is it possible to discern a succession, a chronology, in the variety of Others in the European self-image? Which came earlier, which later? If we study, historically, the discourse and cultural production of non-European hetero-images, silhouetting successive European auto-images, which ones have left older, more deeply-rooted but more occluded traces, which one more recent, visible, superficial ones?

\section{3 Moveable Placenames}

A final caveat. Over longer periods, the meanings of ethnic and geographical appellations shift. Although the Dutch ethnotype has remained fairly stable over the last centuries, the present-day country called The Netherlands is by no means co-extensive with its seventeenth-century or medieval forerunners. Belgium now has little in common with the part of Gaul described by Caesar as inhabited by the Belgae. And Europe has drastically shifted its (imagined) territory and centre of gravity over the millennia. And so the variable geometries that we need to apply involve a changing territory changing its character and self-image through juxtaposition with a changing succession of Others. All of which left echoes and traces in subsequent history.

The resulting complexities are daunting but not insurmountable or overwhelming: the self-profiling of something called 'Europe' is complex, but not chaotic or random. It is possible to discern successive paradigms. Naturally these are anything but homogenous in themselves and within them they carry both the residue of earlier discourse and the germinating anticipations of later developments; but that is almost a given for any historical period, and realisation of this fact cannot justify a defeatist 'non possumus', as if all of history were just a heap of messed-up glop. Continental drift is not measured in miles per hour, not does it proceed at an even rate in a unilinear direction; but directionality there is nonetheless.

The Continental drift in the documentary records of Europe's self-defining discourse, from Hesiod and Herodotus to the EU, can be mapped as a shrinking territory around a shifting centre of gravity. 


\section{Paradigms in Self-Perception}

The aim of this contribution is not to give a full account but rather to indicate some defining paradigmatic moments in order to see what, of all this, carried over into the current discourse of crisis.

\subsection{From Mediterranean Antiquity to Medieval Christendom}

Very broadly, then, ${ }^{4}$ we can see a stage zero when Europe is almost undefined as an area adjoining the Old World, largely maritime, mythically anchored between the Lebanon and Crete, Troy and Ithaca (marked as such by the journeys of Europa and Odysseus). The post-Herodotus Greeks invoke Persia as their contrast-frame, and face westward to a 'European' theatre of maritime communications between Gibraltar and the Black Sea. That Mediterranean footprint remains in force for the Roman Empire: Europe is bounded to the South by the Sahara, to the West by the Atlantic, to the East by the vast empires and deserts of Asia, to the North by the dank forests and chilly plains beyond the Alps. Alexander's sortie towards the Indus and the Nile, Caesar's to the Rhine and the Channel, extend but do not shift this concept of Europe, but Christianity will use the biblical, Sons-of-Noah-derived contrast frame of the Three Continents (Europe, Asia Africa). This post-Roman sense of a European identity will maintain its presence longest in the primacy of Rome and Constantinople (not, significantly, Jerusalem) as the religious capitals of Christendom.

The Others for this Europe are twofold: the nomadic barbarians (Scyths, Goths) roaming over the trackless plains, and the despots ruling their distant Oriental Empires. Both tropes will maintain a very stubborn persistence over the following millennia, albeit overlaid by later shifts and inflections. The role of 'nomadic hordes' is played by the barbarians bringing down the Roman Empire: Goths, Vandals, then also by Huns, Turkic Tatars and Mongols (Attila, Genghis Khan, Timur) from Asia, and Saracens and Arabs bringing Islam from the Middle East. The spread of Islam robs Europe of its southern anchorage: all of the southern coast of the Mediterranean now becomes alien territory, the opposite of Europe; the Mediterranean becomes a moat rather than a pond. Leo Africanus is the last intellectual for whom that sea is still a connecting rather than a dividing presence.

Post-classical Europe defines itself in religious terms as Christendom, and its defining Other for centuries is Islam. At Sankt Gallen, Notker the Stammerer

4 What follows in this section is a digest of Leerssen (2016b) and draws on the sources assembled there. 
notes Charles Martel's victory at Tours as one for the europenses - the first time that that word, 'Europeans', is used. ${ }^{5}$ Upon the completion of the reconquista, centuries later, the Spanish monarchy pursues its further expansion, significantly, not in the Maghreb beyond the Gibraltar straits - that is now firmly alien territory - but in the transatlantic world beyond the Pillars of Hercules. By that time Islam, having been pushed back in the west, is surging in the east: just before the conquest of Granada by the reyes católicos (1492), Mehmet II conquers Constantinople (1453); the Ottomans by then are already established in the Balkans and will expand towards Hungary and the gates of Vienna. That continues to be perceived as a European crisis, from which the continent derives a sense of identity: Enea Silvio Piccolomini (later Pope Pius II) and Charles V repeatedly plead the cause of 'Europe' in the face of Ottoman expansion. Piccolomini felt that the fall of Constantinople was qualitatively different from earlier confrontations with Islam, because it happened within the European ambit: "for in previous times we were wounded in Asia and Africa, that is: in alien lands; but now we have been shaken and stricken in Europe, that is to say in our fatherland, in our own home, in our residence". ${ }^{6}$

\subsection{Becoming Western}

By the time of Leo Africanus and Pius II, Europe as a religious post-Roman empire is fracturing. The Great Schism has turned Rome and Constantinople into opposing rather than complementary centres. And it occurred, fatally, a mere century before the rise of the universities (Bologna, Salamanca, Paris, Oxford). While in Western Christendom, abbey schools developed into universities and monastic learning developed into scholastic learning (Abelard, Aquinas, Roger Bacon), that process remained without parallel in the monastic world of Orthodoxy. As a result, Western Europe by the later Middle Ages had developed a self-image that drew heavily on Latin classics and opposed its pursuit of learning to the stagnant East. The Italian Renaissance and Humanism

5 Gesta Karoli Magni, I:17.

6 Enea Silvio Piccolomini, Constantinopolitana clades, speech held at the Frankfurt Diet, 1454. In the original: "[...] retroactis namque temporibus in Asia atque in Affrica, hoc est in alienis terris, vulnerati fuimus, nunc vero in Europa, id est in patria, in domo propria, in sede nostra percussi cesique sumus". Pius continues that this conquest is much more grievous than previous incursions of the Turks into Greece, or the Tatars into the Don basin, or the Saracens into Spain. ("et licet dicat aliquis ante plurimos annos ex Asia Turchos in Greciam transivisse, Tartaros citra Thanaim in Europa consedisse, Sarracenos Herculeo mari traiecto Hispanie portionem occupasse; numquam tamen aut urbem aut locum amisimus in Europa, qui Constantinopoli possit equari."). Pii II orationes (1755), vol. 1, p. 263f. Quoted in the source material for Helmrath (2007) and also Pius II (2006). 
became defining elements in a European self-image, priding itself on its intellectual curiosity. In the process, the Continent's Eastern half drops out of the European image as stagnant and dominated by uncouth despots. Only the Catholic chivalries of Central Europe (the Teutonic Order, Poles, Hungarians, Croats) maintained a tenuous connection as the self-styled 'bulwarks of Chris-

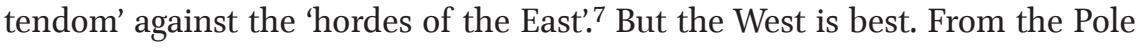
Copernicus to the Italian Galilei to the Englishman Newton, the scientific revolution is a Western affair, and ever more so; so is the growth of global colonialism, which - move over, Marco Polo - uses the Atlantic as Europe's sole path of access to the rest of the globe.

\subsection{Becoming Northern}

A further tectonic shift is introduced by the Reformation, which splits Western Christendom along a polarity soon construed as North vs. South - notwithstanding the fact that Geneva lies well south of Lisieux and Cracow. Crucially, the spread of Lutheranism coincides with the rediscovery of Tacitus's longlost tract Germania, and Luther is immediately framed as a latter-day Arminius-the-Cheruscan, thwarting Roman hegemony North of the Danube and East of the Rhine. ${ }^{8}$ In addition, a classicist temperamental frame comes into universal use opposing the cool temperaments of the cold north (phlegmatic Dutch, melancholic Germans) against the sensuous temperaments of the hot south (sanguine Italians, choleric Spaniards). This overdetermination of temperament, religion and geography becomes a lasting, ingrained stereotype, even influencing Max Weber's notions of a 'Protestant work ethic' motivating the rise of mercantilism and capitalism in North-Western Europe. The Enlightenment will intensify a European notion of a 'Republic of Learning' which is, de facto, anchored in Northern Europe; even its French intellectual denizens (Montesquieu, Voltaire, Diderot) advocate the virtues of moderation and a critical spirit in opposition to Southern Others like absolutist Spain or the Papacy. Actual latitude and longitude have little to do with this: Geneva as Protestant bulwark is a metaphorically Northern city; an eastern despot like Catherine the Great is, by virtue of her intellectualism, her German birth and the cold climate of her realm, metaphorically classified as 'northern'. And to the extent that scientific inquiry is also a eurocentric, ethnographic study of the 'primitive' races of the rest of the world, the encounter with them runs through

7 See Zrinka Blažević's contribution to this book.

8 See Borchardt (1971); Krebs (2011); Leerssen (2016c). On the discourse of climate and temperament underpinning North-South oppositions, the classical work is still Zacharasiewicz (1977). 
the colonial ports and the stock exchanges of the area Paris-London-Copenhagen-Frankfurt, now the centre of a core-Europe shrunk to the continent's North-by-North West.

This core-Europe can identify itself against any number of Others: the ancient empires of Asia; Islam; the nomadic tribes of (sub-)Saharan Africa and central Asia, or the equally nomadic savages of the New World, encountered during the colonial expansion post-1492. In addition, it can also silhouette itself against the tyrannical Romance-language monarchies of Catholic Southern Europe ${ }^{9}$ and the backward, Islam-threatened, feudal polities of Orthodox Eastern Europe. Core-Europe is the final resting place of a semantic-geographical slippage that saw the continent's imagined footprint shift and shrink from the Levantine Mediterranean to the West and then to the North; its centre of gravity moving from the Aegean by way of Rome across the Alps and towards the shores of the North Sea.

All the phases in that slippage process left a discursive repertoire of Othering in their wake with accumulating variants, one layer being superimposed on other, older ones. In the nineteenth century, that entire repertoire received the final overlay of an anxiety about the further possible 'westward course of Empire' towards the US or across the oceans; a Spenglerian Untergang des Abendlandes. The concomitant self-image sees Europe as old, decadent, experienced but feeble, when facing the rise of younger, brasher societies elsewhere. America is ambivalently either Europe's Western extension, further developing its self-attributions of free enterprise, individualism, and a inquisitive spirit, or else Europe's Other, uncivilised, simplistic, reckless, more brawn than brain. ${ }^{10}$

\subsection{Becoming Complex}

After an anguished need to confront the guilt of colonial misrule, world wars and genocide, Eurocentrism has dwindled to a mere vestige of what it used to be. The EU defines itself as post-totalitarian and dedicated to avoiding the reckless mistakes of the past. Europe's contemporary self-image is nothing if not a constant source of self-contradiction and anxiety. Other societies in the world are perceived as simple, one-dimensional, easily characterised; Europe, by contrast is felt to be complex, unintelligible, a maze lost in a labyrinth. Europe is also its own Other, with inner divisions, and the guilt of many bloodstained centuries of world hegemony, culminating in the twentieth-century

$9 \quad$ See Leerssen (2018), pp. 73-89.

10 I note only in passing the projection of this European anxiety on Asia, where 'the awakening of China' has been a constant fear factor since Napoleon, feeding into a 'Yellow Peril' discourse mixed with the old rejection of 'Oriential despotism'. 
dictatorships. Paradoxically, Europe can draw on its guilty conscience to claim a moral superiority vis-à-vis nations like the US or Turkey whose chauvinistic self-celebration - and their lack of guilt vis-à-vis their own genocidal past - is criticised as a symptom of political immaturity. ${ }^{11}$ It is in this aporia that the EU was confronted with the double crisis of an influx of refugees and the rise of xenophobic, populist neo-nationalism. (See below, section 6)

What are the constants and the variables in this succession of self-contrasts against ever shifting Others? The most recent strata, self-doubt, a sense of historical guilt and a sense of being post-totalitarian (culturally expressed in cinematic productions such as Das Leben der Anderen, Il Meglio Gioventù) are to be found largely on the political left where they bolster a sense of cosmopolitanism and anti-xenophobia. The older strata in the self-image are lastingly powerful for the discourse of the European right and centre-right. The image of 'Oriental despotism' - applied as it may be to ancient Persia, the Ottoman Empire and its Turkish successor state, and Russia (Tsarist, Communist or Putinist) - has continued to allow for a European self-identification with the values of liberal democracy, and with the values of the Enlightenment. In spite of ongoing secularisation, Islam is still Europe's most potent Other, particularly so in those Central-European countries still invoking a bulwark function vis-à-vis the Middle East.

The combination of these two auto-images allows for a discourse that despite is self-contradictory nature continues to make for efficient rhetoric: the fact that the European moral heritage consists of a combination of 'JudaeoChristian'12 and 'Enlightenment' values. Strictly speaking, that is as problematic as saying that Europe is characterised by its Socialist and its Free-Enterprise traditions, yet so ingrained is the formula that the public's habituation allows it to persist unchallenged. The two registers share, of course, the negative quality

\footnotetext{
11 See Leerssen (2017).

12 On the antecedents see Sebban (2012). On the contemporary political slogan see Molle (2019). The use of the term reached embarrassing depths when the German antiimmigration politician Horst Seehofer in March 2018 denounced Islam as being fundamentally alien to Germany with its 'christlich-jüdisch' historical imprint. Seehofer's anti-Islamism (and the public's preoccupation with that anti-Islamism) tended to draw attention away from the statement's jaw-dropping tastelessness: historically characterising what is, after all, the Third Reich's successor state by vaunting a claim to Jewish heritage for xenophobic purposes. See Bau (2018) and Vollmer (2018).
} 
that both implicitly contrast Europe as a Western sphere to a despotic, Islamic Orient. Islam can be used as Europe's contrast-frame both by those who reject it as un-Christian and by those who reject it as being illiberal. ${ }^{13}$

The north-south opposition feeds into contemporary austerity debates, particularly during the European debt crisis of 2009-12 where Mediterranean countries are opposed to a mistrustful northern Euro-zone dedicated to austerity measures and suspecting the Southern partners of profligacy and lack of proper financial accountability. ${ }^{14}$

The current political debates in Europe align various opposing policies with conflicting visions of what Europe is; and as a result, any conflict in Europe takes on the intensity of a conflict of identity, an existential crisis, something 'the European project' may not be able to survive.

Recent Others: A Swarm

Meanwhile Europe, post-1945, is being confronted by a new set of others: immigrants. These are an extremely diverse presence in the continent. They range from ex-colonial citizens (Algerian-born in France, West-Indies-, South-Asiaand Africa-born in the UK, Indonesia- and Surinam-born in The Netherlands) to immigrant labour (Italians, Greeks, Turks, Moroccans) attracted for mining or industrial employment in 1950s-7os Belgium, The Netherlands and Germany. Since 1989, refugees have sought sanctuary in Europe from war zones, tyrannical regimes and calamitous hardship in the Middle East and Africa.

The people habitually grouped together as 'immigrants' have very few common denominators either as to their geographical origin, the historical forces that impelled their migration into Europe, or even the period of their arrival. Accordingly, they are framed in their non-territoriality as a roaming 'swarm' or a 'horde', without specific link to a home country (as was the case in traditional ethnotypes). Their very heterogeneity marks them solely in the negative aspect of their not being native-rooted Europeans, and as such they are framed very differently from other transients in the European landmass such as post1945 Displaced Persons (liberated from the dictatorships' camps or driven from their homes by war or mass expulsions) or the modern-day tourists who are

13 An added irony is that it is often illiberal populists who denounce Islam for falling short of liberal values such as women's emancipation or acceptance of homosexuality. See Uitermark, Mepschen, Duyvendak (2014). 
now causing increasing friction in over-popular cities like Venice, Rome, Barcelona and Amsterdam. ${ }^{15}$

The generic non-characteristic as 'non-European' is remarkable because it overrides the usual contrast-frame as non-English, non-French etc. and thus, ironically, manifests an implicit European, rather than national, auto-image at work. It provokes unspecific and unfocused xenophobia, not linked to any specific character attributes or ethnotypes other than a perceived diminution of European authenticity and a tendency towards lawlessness and a disruptive effect on the fabric of society and the stability of the economy. This xenophobia recalls that aimed at earlier non-territorial alterities, Jews and Roma ('Gypsies'): Others within, rather than outside, the territorial boundaries of Europe. Tourists, a more transient 'swarm', do not present a transgenerational presence or a burden on economic resources (except in driving up real estate prices), and they are driven by a desire for entertainment rather than by dire necessity; but even so, they too are increasingly resented for their alienating impact and disruptive behaviour.

That contrast-frame, shared, in what must be the bitterest of irony, by hedonistic tourists and traumatised refugees alike, alerts us to what is perhaps the oldest and most persistent contrast-frame of all in the European self-image: that of roaming nomads vs. a local, orderly and sedentary society.

\section{7}

\section{Domesticity}

Among the core pantheon of the Roman Dii consentes, the ruling city deities, was Vesta. No shape-shifting, philandering or foe-slaying myths are associated with her as they are with the other gods. Instead she is best known for being worshipped in the eternal household fire tended by the Vestal Virgins, one of the most enduring city cults of ancient Rome. ${ }^{16}$ Like her Greek analogue Hestia, Vesta symbolizes both the domestication of fire as a tool of civilisation, and the principle of living in fire-centered houses, with a roof over one's head,

15 The pied noirs who moved to France after Algerian independence can be ambivalently categorised either as 'intra-European Displaced Persons' or as 'extra-European foreigners from overseas'. Tourists are on the whole non-sedentary and (as individuals) a short-term presence; even where they acquire real estate as 'expats' (e. g. Britons in Spain) this is usually at an age when they do not start families in the country of arrival. They are also a mixed group consisting of Europeans and non-Europeans alike. Rich expats in places like London or Monte Carlo (Russian 'oligarchs' and Middle-Eastern 'oil sheikhs') are an ambivalently framed group.

16 See Goux (1983). 
a fireplace in the middle, and a threshold separating the inner sphere of cleanliness from the mundanity of the world outside. ${ }^{17}$ Like Janus, the threshold deity (cf. Latin ianua, 'doorway'), and the Lares and Penates, she was a goddess of domesticity and ordered stability, requiring only the dutiful observance of maintaining the hearth-fire in the house; as such her worship was private as much as public. Indeed the temple of Vesta, constructed on the plan of a traditional Roman domus, can be seen as the city's very fireplace, turning the entire city metaphorically into a meta-house.

The domestic centrality of the fireplace, and its architectural location at the inner core of the house-dwelling (as its Latin name, focus, suggests) provide a potent auto-image against which all societies stood out as barbarians who cooked their food out of doors, under the open sky. Very deeply embedded in the European self-image lies its opposition to nomadism and camp-fires, its reliance on ordered stable domiciles with a tended fire at their centre and a roof over their head. Against this auto-image, anyone living in encampments with campfires stands out as an alien - be he a Bedouin, a Gypsy, a nomad or a refugee.

The notion of domesticity may amount to an 'absolute metaphor' in Hans Blumenberg's sense of the word. In Blumenberg's view, certain metaphors are so ingrained and fundamental to our conceptualisation of the world that they are not just associative similes tagged on to our primary concepts, but rather intrinsic elements of our understanding. ${ }^{18}$ Seeing society as an extension of one's household is such an absolute metaphor; the use of oikos (the Greek word for household) in terms like 'ecology' or 'economy' indicates this. ${ }^{19}$ Likewise the word 'domestic', derived from domus, 'house, home' is non-metaphorically, immediately, applied to whatever occurs within our own society as opposed to the world outside it. ${ }^{20}$

The conceptual opposition between an ordered world inside the walls and a violent, unruly wilderness outside, can be traced back as far as Heraclitus's dictum that "We should protect the laws as if they were our city walls". 21

17 The classic theory on the demarcation clean-unclean remains Douglas (1966).

18 The idea of an 'absolute metaphor' was outlined in Blumenberg (1960) and further elaborated in Blumenberg (1979a) and Blumenberg (1979b).

19 See Nagle (2006). On the oikos in economic thought from Aristotle to Marx see Booth (1993).

20 There is a considerable body of reflection on 'making oneself at home in the world', e. g. Bollnow (1963). A recent, keen analysis of the home-affect is Duyvendak (2017).

$21 \quad K a h n$ (1979), p. 59 (nr. LXV). Kahn comments p. 179 that Heraclitus elsewhere compares violence and lawlessness (hybris) to a house on fire. This underscores the parallel between two oppositions: on the one hand between order and chaos, and on the other hand between inner sphere and outside. For a political elaboration of this idea, see Eijsbouts (1993) and Leerssen (1999). 
Europe as domesticity: on closer scrutiny, examples turn out to suffuse the European discourse of self-identification and othering over long periods. Prior to the crisis of $145^{2}$ (to recall Pius II's qualification of Europe as 'our own home, our residence'), Giraldus Cambrensis, writing in 1188 in his Topographia Hibernica, had already activated the contrast-frame when evoking the savage lack of civility of the native Irish as being, almost literally, 'beyond the pale'. The Irish are, as he puts it,

forest-dwellers, and inhospitable; a people living off beasts and like beasts; a people that still adheres to the most primitive way of pastoral living. For as humanity progresses from the forests to the arable fields, and towards village life and civil society, this people is too lazy for agriculture and is heedless of material comfort; and they positively dislike the rules and legalities of civil intercourse; thus they have been unable and unwilling to abandon their traditional life of forests and pasture. ${ }^{22}$

The stadialism is unmistakable: proper, regulated society is organised in cities and villages, subject to the rule of law, and with a reliable, industrious subsistence in the form of agriculture and trade. The hand-to-mouth life of nomads falls below this standard, roams around in territorially unmarked forests, and is closer to the life of animals than to that of proper humans. Concomitantly, the Irish have no regulated family life: "They pay no tithes or harvest sacrifices, they do not celebrate marriage, they shun no unchastity and neglect to visit God's church with the necessary respect."23

\section{$8 \quad$ Family Values}

Any reader will, upon reflection, realize that the xenophobic Othering of migrants will invariably frame them as unattached single males. The notorious 'Breaking Point' poster that fed the British Brexit campaigns showed long waiting crowds of migrants at a border crossing point in Slovenia, glaring ominously at the British electorate in their intent to approach Britain by way of Europe; ${ }^{24}$ and the salient characteristic that they had in common was that they were an aggregate of single, male individuals. This, of course, is a characteristic also of any invading army: women and children rarely form the frontline of attacking storm troopers. A very deep-seated schematisation in such

\footnotetext{
22 Giraldus Cambrensis (1982), p. 162 f.

23 Giraldus Cambrensis (1982), p. 166.

24 See Morrison (2016).
} 
representation is that the threatened domestic space is familial, inhabited by wives and children, and the invaders are violent hordes of males. As the Marseillaise has it: "Entendez-vous, dans les campagnes, / mugir ces féroces soldats? / Ils viennent jusque dans nos bras égorger nos fils, nos compagnes."25

Thus, the hordes of untrustworthy single males were implicitly aligned with an invading army and implicitly opposed to an English domesticity exemplified, in that precise period, by the familial and social harmony of that decade's exemplification of domestic Englishness, Downton Abbey - an Englishman's home which is, quite literally, a castle, as well as a feel-good comfort zone for the viewers.

Conversely, any representation that evinced sympathy for the plight-driven migrant would evoke them as being, indeed, familial: couples with children, driven from their home by féroces soldats and as such deserving shelter and sympathy. As evocative as the picture of the waiting male crowds was that of the drowned toddler washed up on a Greek beach. A counter example of a policy of welcoming and sheltering refugees was the Canadian one, which was invariably framed, also in the accompanying press coverage, as welcoming refugee families. ${ }^{26}$

\section{9}

\section{Securing the Perimeter}

How do we frame Europe? The contemporary crisis discourse draws on a very long-standing image of Europe's Others as nomads, be they Wild Irish, Mongols or Tatars, Saracens, Bedouins or Arabs (or native Americans and Australians, later on). Their telling characteristic is, almost tautologically, that they have no houses. Without fixed indoor fireplace at the inner core of their dwelling, they live in moveable tents or conveyances and their fireplaces are typically outside, under the open sky. Camp fires as opposed to hearths. Aimless, plundering mobility rather than ordered, sedentary existence within domestic or city walls. The implied European self-image draws on the notion of an ordered household, whose thresholds must keep the polluting dangers from the outside world at bay and maintain the inner order, which is domestic both in the

25 "In our lands can you hear those fell soldiers howl? / They come to cut the throats, even in our embrace, of our children and our women." [Transl. J. L.].

26 Compare the website of the Canadian Council for Refugees, ccrweb.ca/en/psr-toolkit/ other-useful-info-family-reunification; any google search for 'Canada refugee family' will bear out the point. 
sense that it draws on the house-metaphor and on the notion of the family as its rightful occupant.

Europe in its early-twentyfirst-century crisis has two borders with its newly emerging Other. One is physical: it consists of non-domestic spaces of transient occupancy: 'supermodern' non-lieux (in Augé's sense) ${ }^{27}$ such as airports, motorway rest areas, tourist campsites; and - most disturbing of all - refugee and immigration detention camps, those spaces identified by Giorgio Agamben as being outside the state's proper governance and in a "State of Exception". 28

Europe's other border with the outside world is mental, and now dominated by a manipulative discourse weaponising deeply-ingrained 'absolute metaphors' like home and family for the purpose of xenophobic rhetoric. To understand that rhetoric properly, the mere analysis of ethnotypes proves to be insufficient, and may almost collapse into the demonstration that the discourse of Othering Others is ethnocentric - a vapid pleonasm if there ever was one. How that discourse functions involves the instrumentalisation and skewed distribution of absolute metaphors of a moral nature - where 'moral', in the root sense (as derived from the Latin mores), refers both to a set of accustomed, ingrained behavioural patterns and to a value-system rationalising those patterns by means of value judgements. Nationalism post-1989 may well take the form of the nation's moral monopolisation of something as cute and uncontentious as 'family values' - trivial, banal entertainments like Downton Abbey and The Great British Bake-Off accompanying, and covertly justifying, the logic of Brexit.

\section{Bibliography}

Agamben, Giorgio (2004). State of Exception (Chicago: University of Chicago Press).

Augé, Marc (1992). Non-Lieux. Introduction à une anthropologie de la surmodernité (Paris: Seuil).

Bau, Walter (2018). 'Von Wulff bis Seehofer. Gehört der Islam zu Deutschland?, Berliner Morgenpost, 16 February. www.morgenpost.de/politik/article213737863/Von-Wulffbis-Seehofer-Gehoert-der-Islam-zu-Deutschland.html [accessed 24.06.2019].

Beller, Manfred, Joep Leerssen (eds) (2007). Imagology. The cultural construction and literary representation of national characters. A critical survey (Amsterdam, New York: Rodopi).

$27 \quad$ See Augé (1992).

28 See Agamben (2004). 
Blumenberg, Hans (1960). 'Paradigmen zu einer Metaphorologie', Archiv für Begriffsgeschichte, 6, pp. 5-142. Book reprint (1997).

Blumenberg, Hans (1979a). Arbeit am Mythos (Frankfurt a.M.: Suhrkamp).

Blumenberg, Hans (1979b): Die Lesbarkeit der Welt (Frankfurt a.M.: Suhrkamp).

Bollnow, Otto Friedrich (1963). Mensch und Raum (Stuttgart: Kohlhammer).

Booth, William James (1993). Households. The Moral Architecture of the Economy (Ithaca: Cornell University Press).

Borchardt, Frank L. (1971). German Antiquity in Renaissance Myth (Baltimore: Johns Hopkins University Press).

Douglas, Mary (1966). Purity and Danger. An Analysis of the Concepts of Pollution and Taboo (London: Routledge \& Kegan Paul).

Duyvendak, Jan Willlem (2017). Thuis. Het drama van een sentimentele samenleving (Amsterdam: Amsterdam University Press).

Dyserinck, Hugo (2015). Ausgewählte Schriften zur Vergleichenden Literaturwissenschaft (Berlin: Frank \& Timme).

Eijsbouts, Willem Thomas (1993). 'Borders and Democracy. The Schengen Treaties', Yearbook of European Studies, 6, pp. 57-70.

Giraldus Cambrensis (1982). The History and Topography of Ireland (Harmondsworth: Penguin).

Goux, Jean-Joseph (1983). 'Vesta, or the place of being', Representations, 1, pp. 91-107.

Helmrath, Johannes (2007). 'Enea Silvio Piccolomini (Pius II.). Ein Humanist als Vater des Europagedankens?', Themenportal Europäische Geschichte. www.europa. clio-online.de/essay/id/fdae-1327 [accessed 24.06.2019].

Kahn, Charles H. (1979). The Art and Thought of Heraclitus. An Edition of the Fragments with Translation and Commentary (Cambridge: Cambridge University Press).

Krebs, Christopher B. (2011). A Most Dangerous Book. Tacitus's "Germania" from the Roman Empire to the Third Reich (Cambridge, Mass.: Harvard University Press).

Leerssen, Joep (1999). 'Law and Border. Were and How we Draw the Line', Irish Review, 24, pp. 1-8.

Leerssen, Joep (2016a). 'Imagology. On invoking ethnicity to make sense of the world', Iberic@l, Revue d'études ibériques et ibéro-américaines, 10, pp.16-31.

Leerssen, Joep (2016b). Spiegelpaleis Europa. Europese identiteit als mythe en beeldvorming (3rd edn Nijmegen: Vantilt).

Leerssen, Joep (2016c). 'Tribal Ancestors and Moral Role Patterns', in Joanne Parker (ed.), The Harp and the Constitution. Myths of Celtic and Gothic Origin (Leiden: Brill), pp. $13^{-25}$.

Leerssen, Joep (2017). 'Stranger/Europe', in Acta Universitatis Sapientiae (Philologica), 9.2, pp. $7-25$.

Leerssen, Joep (2018). National Thought in Europe (3rd edn Amsterdam: Amsterdam University Press). 
Molle, Andrea (2019). 'Religion and Right-wing Populism in Italy. Using "Judeo-Christian roots” to Kill the European Union', Religion, State and Society, 47.1, pp. 151-168.

Morrison, James (2016). 'Break-Point for Brexit? How UKIP's Image of "Hate” Set Race Discourse Reeling back Decades', EU Referendum Analysis 2016. www.referendumanalysis. eu/eu-referendum-analysis-2016/section-5-campaign-and-political-communication/ break-point-for-brexit-how-ukips-image-of-hate-set-race-discourse-reeling-back-decades/ [accessed 24.06.2019].

Pii II orationes politicae et ecclesiasticae (1755-1759), ed. by Johannes Dominicus Mansi. 3 vols (Lucca: Benedinus).

Pius II (2006). 'Enea Silvio Piccolomini über Europa und die Türken. Auszüge aus "Asia”, “De Europa”, “Constantinopolitana clades", "Epistula ad Mahometem”, 14541461', Themenportal Europäische Geschichte. www.europa.clio-online.de/quelle/id/ q63-28286 [accessed 24.06.2019].

Sebban, Joël (2012). 'La genèse de la "morale judéo-chrétienne". Étude sur l'origine d'une expression dans le monde intellectuel français', Revue de l'histoire des religions, 1, pp. 85-118.

Sierp, Aline (2017). 'Dividing United Europe. Stereotypes, Prejudices and the European (Economic) Crisis', National Identities, 19.1, pp.1-9.

Uitermark, Justus, Paul Mepschen, Jan Willem Duyvendak (2014). 'Populism, Sexual Politics, and the Exclusion of Muslims in the Netherlands', in John R. Bowen et al. (eds). European States and their Muslim Citizens. The Impact of Institutions on Perceptions and Boundaries (Cambridge: Cambridge University Press), pp. 235-255.

Vollmer, Frank (2018). 'Christlich-jüdisch? Anmaßung!', RP Online, 30 April. https://rponline.de/politik/christlich-juedisch-anmassung_aid-22209073 [accessed 24.06.2019].

Zacharasiewicz, Waldemar (1977). Die Klimatheorie in der englischen Literatur und Literaturkritik von der Mitte des 16. bis zum Ende des 18. Jahrhunderts (Vienna: Braumüller). 